\title{
HOW CARTELS PUNISH: A STRUCTURAL THEORY OF SELF-ENFORCING COLLUSION
}

\author{
Ian Ayres*
}

\section{INTRODUCTION}

Structural theories of collusion posit that demand and supply characteristics of an industry's structure can be used to determine the likelihood of anticompetitive cooperation by competitors. ${ }^{1}$ A variety of structural approaches have been advocated by academics ${ }^{2}$ and applied by both enforcement agencies ${ }^{3}$ and courts. ${ }^{4}$

* Law Clerk to the Hon. James K. Logan, United States Court of Appeals for the 10th Judicial Circuit; Assistant Professor, Northwestern University School of Law (beginning August 1987); Research Fellow, American Bar Foundation (beginning August 1987). B.A. Yale University, 1981; J.D. Yale University, 1986; Ph.D Candidate (Economics), Massachusetts Institute of Technology.

1 thank John Donohue, Henry Hansmann, Al Klevorick, George Priest, Garth Saloner, Steven Salop, Richard Schmalensee, Louis Schwartz, Oliver Williamson, and participants of seminars at Cardozo, Duke, Emory, Iowa, Northwestern, and Yale for valuable comments. Financial support from the Yale Center for Studies in Law, Economics and Public Policy is gratefully acknowledged.

1. Structural theories have many antecedents. See, e.g., G. Stigler, A Theory of Oligopoly, in The Organization of Industry 39-63 (1968); Hay \& Kelley, An Empirical Survey of Price Fixing Conspiracies, 17 J.L. \& Econ. I3 (1974). More generally, these theories follow the Structure-Conduct-Performance (S-C-P) paradigm of Joseph Bain, under which structural variables (such as seller concentration) were modeled to affect conduct variables (such as collusion or competition) which in turn were to affect performance variables (such as profits). J. Bain, Industrial Organization 43 (2d ed. 1968). Although conduct can conversely affect structure, see, e.g., infra note 4 (predatory behavior will influence seller concentration), such feedback effects are beyond the scope of this Article. Bain's S-C-P paradigm has gained widespread acceptance. See, e.g., F. Scherer, Industrial Market Structure and Economic Performance 3-7 (2d ed. 1980); Weiss, The Structure-Conduct-Performance Paradigm and Antitrust, 127 U. Pa. L. Rev. 1104 (1979).

2. For example, Judge Richard Posner has championed a structural approach for detecting and punishing antitrust collusion. See R. Posner, Antitrust Law: An Economic Perspective 55 (1976); R. Posner \& F. Easterbrook, Antitrust: Cases, Economics Notes and Other Materials 336 (1981); 6 P. Areeda, Antitrust Law I 1430, at 178-82 (1986).

3. The Federal Trade Commission has examined structural characteristics to focus investigative resources on suspect industries. For a history of the FTC's attempts at targeting collusion, see D. Pender \& M. Coate, Case Generation and Remedies 8 (F.T.C. Collusion Project Working Paper No. 3, June 29, 1984) (unpublished paper on file at the Columbia Law Review).

4. At least one court has considered structural evidence as a plus-factor for inferring the actual existence of collusion. See, e.g., Wall Products Co. v. National Gypsum Co., 326 F. Supp. 295 (N.D. Calif. 1971) (stressing structural characteristics of the relevant market that predisposed it to collusion); see also R. Posner, supra note 2 , at $73 \&$ $\mathrm{n} .52$ (discussing implications of case).

While this Article investigates how structure affects collusive behavior-that is, efforts to make competitors cooperate-the structural approach also applies to identifying 
Any structural theory, however, must at bottom rest on an understanding of the necessary conditions for collusion. To collude effectively, firms must be able (1) to reach an agreement, (2) to detect breaches of the agreement, and (3) to punish firms that breach. ${ }^{5}$ Advocates of the structural approach have suggested a variety of market characteristics that affect these conditions. Some characteristics (such as seller concentration, or the homogeneity of the product) relate to the ease of reaching an agreement; others (such as stable demand, or announcement of the lowest sealed bid) affect the ability to detect price-cutting breaches. However, none of the structural variables currently considered by academics or enforcement agencies ${ }^{6}$ relate to the third condition for successful collusion-the necessity of being able to punish breach; thus the current list of structural variables is systematically incomplete. This omission of variables affecting the ability to punish may explain the empirical failure of the structural approach to identify collusion. ${ }^{7}$

Focusing on the necessity of self-enforcement can also serve to harmonize economic and legal conceptions of collusion. Legal scholars have traditionally distinguished between explicit and tacit collusion. ${ }^{8}$ The law punishes the former, so that the act of communication is of central importance. ${ }^{9}$ For economists, however, this distinction has no

the likelihood of exclusionary behavior-that is, efforts to exclude competitors from a market. For example, a structural analysis could be used to analyze the feasibility of the exclusionary practice of predatory pricing. See Joskow \& Klevorick, A Framework for Analyzing Predatory Pricing Policy, 89 Yale L.J. 213, 225-31 (1979).

5. See Osborne, Cartel Problems, 66 Am. Econ. Rev. 835, 835 (1976). A cartel must also be able to deter the entry of new competitors-so that variables tending to indicate the presence of barriers to entry would be appropriate under the structural approach. Entry deterrence, however, can be considered a cartel agreement with potential competitors not to enter rather than an agreement with existing competitors.

6. For a complete list (of more than 25 variables), see M. Coate, The Application of the Structure-Conduct-Performance Theory to Oligopolistic Industries (May 1984) (unpublished manuscript on file at the Columbia Law Review). Factors favoring the ability to reach agreement are: high seller concentration, a small number of sellers, low buyer concentration, a large number of buyers, similar buyers, inelastic demand at the competitive price, a homogeneous product, industry competition based on price, similar vertical integration, similar cost structure, nondurable products, high transportation costs, high fixed to variable costs, single product technology, numerous antitrust convictions, a history of regulation, social structure, similar future expectations, similar future opportunities, and entry barriers. Id. at 40. Factors favoring the ability to detect breach are: sealed bidding, frequent small orders, static or declining demand, predictable demand, and sale of products separately. Id.

7. Frederick Scherer, a former Director of the Federal Trade Commission's Bureau of Economics, summed up his experience with the structural approach: "While I was with the FTC, we had an active effort to identify potential price-fixing cases using only structural evidence. The kindest thing I can say about the effort is that it was a resounding flop." Scherer, Book Review, 86 Yale L.J. 974, 982-93 (1977).

8. See Turner, The Definition of Agreement Under the Sherman Act: Conscious Parallelism and Refusals to Deal, 75 Harv. L. Rev. 655 (1962).

9. Theatre Enterprises v. Paramount Film Dist. Corp., 346 U.S. 537, 541 (1954) 
meaning. 10 In game theory models of collusion, the term "agreement" does not imply a formal communication-all that is needed is for the cartel members to have an "understanding" of how others will react to their behavior." ${ }^{11}$ Such shared beliefs-whether acquired tacitly or not-can support a self-enforcing, collusive equilibrium. The analysis in this Article will thus have policy implications for both tacit and explicit collusive agreements. Since tacit agreements can also be self-enforcing, the theory provides no clear reason for exempting such collusion from the concern of antitrust.

Note, though, that the meeting of the minds involved in even an explicit cartel agreement is very different from the meeting of the minds in the normal contractual setting. Part of a legal agreement is the intention that it be susceptible to legal enforcement. ${ }^{12}$ Not only is such intention absent from cartel agreements, these agreements must in fact include their own enforcement rules. The ability of a cartel to punish is essential because courts will not remedy the breach of an illegal contract. (In fact, by revealing the existence of collusion, the plaintiff could face criminal prosecution.)

This Article extends and refines the structural approach by identifying variables that would let us differentiate industries by the ability of colluding firms to punish breaches of a collusive agreement. The ability to punish crucially depends upon the credibility of punishment. This Article provides a rigorous definition of credibility and analyzes what influences the credibility of various punishments. Threats of punishment that are not credible will not facilitate collusion. Part I presents a general theory of self-enforcing collusion supported by credible punishments.

Part II catalogs structural variables that might influence the ability to punish. Colluding firms can punish by either decreasing the demand or increasing the costs of breaching firms. Demand-side punishments are especially important because a firm's demand is usually much more

("Circumstantial evidence of consciously parallel behavior may have made heavy inroads into the traditional judicial attitude toward conspiracy; but 'conscious parallelism' has not yet read conspiracy out of the Sherman Act entirely."); see also 6 P. Areeda, supra note 2, at I 1405 (discussing proof of agreement).

10. Economists instead distinguish between "cooperative" and "non-cooperative" games-with the difference being that cooperative game players can enter into legally enforceable agreements. G. Owen, Game Theory 133 (1982). All game-theoretic models of cartel collusion are therefore explicitly "non-cooperative." But non-cooperative behavior, in the game-theoretic sense, does not foreclose firms from colluding. See Friedman, A Noncooperative View of Oligopoly, 12 Int'l Econ. Rev. 106 (197I) (collusive outcomes could be sustained in a non-cooperative equilibrium if credible punishments were sufficiently high).

11. See J. Szep \& F. Forgo, Introduction to the Theory of Games xvii (1985).

12. See O'Reilly v. Mitchel, 85 Misc. 176, 148 N.Y.S. 88 (Sup. Ct. 1914); Mitzel v. Hauck, 78 S.D. 543, 105 N.W.2d 378 (1960); Balfour v. Balfour, 2 K.B. 571, 579-80 (C.A. 1919) (promises were "not intended by either party to be attended by legal consequences"). 
dependent on the actions of competitors than a firm's costs. For example, rivals can drastically affect a firm's demand simply by changing their own prices. This Part begins then by analyzing how price can be used as a demand-side punishment and examines how industry characteristics can limit the availability of such pricing punishments. It also presents an account of nonprice demand-side punishments and suggests an explanation of their causes.

Also analyzing supply-side punishments, Part II extends Salop's work ${ }^{13}$ on exclusionary practices that "raise rivals' costs." It shows that exclusive dealing or price squeezes can also be used to support collusion by raising a breaching firm's costs after a breach has occurred. Following Williamson's work on "hostage" exchanges that facilitate vertical agreements, ${ }^{14}$ it shows how joint ventures and product exchanges could serve as hostages that commit firms to more effective punishment even before a breach occurs.

Exploring the implications of the preceeding analysis, Part III examines the unique importance of interest rates upon the incentives to collude. Additionally, Part IV reveals how cartel punishments can be disguised within otherwise legal arrangements so as to enlist the state's assistance in enforcing collusive agreements. Part $\mathrm{V}$ discusses how identifying and distinguishing the ability to punish allows policy makers to target enforcement efforts, identify actual episodes of punishment, and promote structural characteristics that constrain collusion.

\section{The Necessity of Credible Punishment}

Because the State will not enforce collusive contracts, ${ }^{15}$ such agreements must be self-enforcing-that is, parties to the agreement must find methods of punishing breach themselves. ${ }^{16}$ Indeed, even the simplest prisoner's dilemma game ${ }^{17}$ shows that the ability to punish is a precondition of collusion. Even if the players have unlimited time to reach an agreement, and even if they know instantaneously when "finking" occurs, they will both choose to fink on an agreement that cannot

13. See, e.g., sources cited infra note 58 .

14. See, e.g., sources cited infra note 67 .

15. See United States v. Trans-Missouri Freight Ass'n, 166 U.S. 290, 341-42 (1897); 15 U.S.C. § 1 (1982) (declaring illegal "[e]very contract, combination . . or conspiracy in restraint of trade or commerce.").

16. See Telser, A Theory of Self-Enforcing Agreements, 53 J. Bus. 27 (1980). While State enforcement serves multiple goals-including compensation to nonbreaching firms-self-enforcement turns solely on punishment to deter breach.

17. In the prisoner's dilemma game, two criminals must choose independently a strategy whether or not to inform, or "fink," on the co-conspirator. Because finking is the dominant strategy, the game demonstrates why there is no honor among thieves. The essence of the prisoner's dilemma is that the punishment of each prisoner is greater than would have occurred had enforceable cooperation been possible. See G. Owen, supra note 10, at 129 (giving formal description of the game); Huber, Book Review, 93 Yale L.J. 1148, 1150-51 (1984) (describing prisoner's dilemma game). 
be enforced. ${ }^{18}$

This self-enforcement constraint creates a crucial relationship between punishment and a firm's decision whether to breach. Most generally, a firm will abide by a collusive agreement only if

$$
\text { Profit }_{\text {breach }}<\text { Loss }_{\text {punishment }}
$$

where "Profit ${ }_{\text {breach" }}$ refers to the additional profits that a firm expects to make from breaching the collusive agreement in the current period,

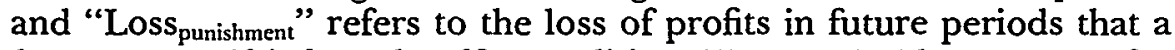
firm expects if it breaches. ${ }^{19}$ Condition (1) must hold separately for each colluding firm if no breach is to occur.

Traditionally, we think that firms collude by fixing a super-competitive price and that pricing slightly below this price (price chiseling) constitutes the breach of the collusive agreement. ${ }^{20}$ A firm can increase its short-term profits by price chiseling because with slightly lower prices it can capture a substantial portion of the industry's profitable sales.

\section{A. The Profits from Breach}

An upper limit on the size of the additional profits from breach can be derived if we assume that the firms' products are perfect substitutes. The assumption of perfect substitutability implies that by reducing price slightly, a breaching firm can capture the entire market demand. ${ }^{21}$ In an industry with $N$ cartelized firms and constant marginal costs, consider a cartel ${ }^{22}$ that restricts output and divides production equally among the $N$ firms, with each firm earning cartel profits, Profit cartel. An $^{\text {A }}$ individual firm that decides to breach the cartel agreement by charging slightly less than the cartel price can increase its production $N$-fold and its profits by approximately

$$
\text { Profit }_{\text {breach }}=(\mathrm{N}-1) \text { Profit }_{\text {cartel}} \text {. }
$$

18. To isolate the importance of cartel punishment in the following analysis, cartels are assumed to reach agreement and detect defection costlessly; additionally, it is assumed that no firms can enter the cartel's industry. See infra notes $28 \& 135$ and accompanying text for discussion of how the need for reaching agreement and detecting breach interacts with the punishment prerequisite.

19. This analysis explicitly assumes a model in which firms breach and punish in different, discrete time periods.

20. See Landes, An lntroduction to the Economics of Antitrust, in R. Posner \& F. Easterbrook, supra note 2, at 1065-66.

21. This limitation also assumes that firms are not capacity constrained. See infra notes 29, 39-41 for discussion of capacity constraints.

22. A cartel is a group of firms that agree explicitly or tacitly to collude on price or other competitive factors. For a discussion of the difference between explicit and tacit collusion, see supra notes 8-12 and accompanying text, infra notes 118-24 and accompanying text.

23. Under this extreme assumption of perfect substitutability, a firm that undercuts the cartel price by an infinitesimally small margin could come arbitrarily close to earning the total cartel's profits of all firms in the cartel, $N \times$ Profit $_{\text {-artel, a gain of }(N-1) \times}$ Profit $_{\text {r.rnct }}$ over what it would earn if it did not breach. If, however, the market were 
By fixing a more competitive price, firms in a cartel could lower their profits, Profit ${ }_{\text {cartel, }}$ and therefore lower the possible profits from

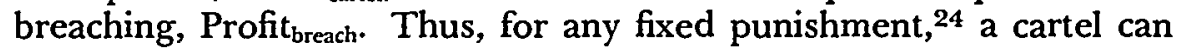
satisfy the no-breach requirement of condition (1) by lowering the cartel price sufficiently. This insight suggests that higher punishments could support greater collusive profits, ${ }^{25}$ and that cartels will not always act as a monopolist would.

This second point is especially important since a recurring approach to antitrust begins by asking whether observed behavior is consistent with the behavior of a monopoly firm. If it is not consistent, the inference is that competition must exist. ${ }^{26}$ However, once we appreciate how punishments relate to self-enforcement, the alternative to monopoly behavior as an explanation is not necessarily competition, but may well be intermediate types of collusive behavior-as cartels attempt to reduce the profits from breach in order to make collusion selfenforcing. ${ }^{27}$

The profits from breach can be limited by the speed of cartel retaliation. Inherent in the concepts of breach and punishment is the idea that a breach must temporally precede any punishment. It is during this temporal gap that the profits from breach are made. The ability to detect breach can limit these profits by reducing this interval-the faster the breach can be detected, the sooner the punishment can commence. ${ }^{28}$ Indeed, if breaches could be detected instantaneously, the

characterized by product differentiation (so that products were not perfect substitutes), the profits from breach would be lower.

24. The conditions under which the cartel punishment is not fixed (that is, varies with Profit carcl $_{\text {) }}$ are discussed infra note 83 and accompanying text.

25. As used here, a punishment will "support" a given degree of collusion if the nobreach requirement of condition (1) is satisfied. Even high cartel punishments, however, cannot support cartel profits higher than those of a monopoly. This is true even if price discrimination is possible. If a cartel has been price discriminating as a monopolist, a breaching firm could analogously capture the industry's profits by slightly undercutting each of the cartel's various prices.

26. Posner, for example, argues that the dramatic rise of cigarette prices while demand dropped during the Depression was inconsistent with monopoly behavior, and that therefore there was no satisfactory economic basis for the view that the producers were conspiring to monopolize. See, e.g., Posner, Oligopoly and the Antitrust Laws: A Suggested Approach, 21 Stan. L. Rev. 1562, 1585-87 (1969). Even so, such price increases are equally inconsistent with competitive behavior.

27. See, e.g., Rotemberg \& Saloner, A Supergame-Tbeoretic Model of Price Wars during Booms, 76 Am. Econ. Rev. 390 (1986) (cartel punishment model incorporating possibility of intermediate collusion); I. Ayres, Deriving Cartel Behavior in a Model with Fringe Competition 10-11 (July 10, 1986) (unpublished manuscript on file at the Columbia Law Review) (cartel may prefer less collusive behavior that supports large collusive group).

28. This fact-that punishment must occur after breach-also implies that the future profits lost due to punishment must be discounted to their present value in condition (1). The interest (or discount) rate then becomes an important structural characteristic. See infra notes 82-92 and accompanying text. 
profits from breach would be driven to zero because firms could punish immediately by charging the competitive price. Firms consequently would have no incentive to breach collusive agreements. When detection is not immediate, the relative magnitude of loss due to punishments becomes important in determining whether an agreement will be self-enforcing. Thus, by taking account of the ability to detect breaches, the current structural approach analyzes the determinants and probable size of the profits from breach, the left hand side of condition (1). ${ }^{29}$ The thrust of this Article, conversely, is to analyze the determinants of the right hand side of condition (1)-the ability to punish.

\section{B. The Lost Profits from Punishment}

Although the foregoing analysis indicates that a cartel will want to set punishments as high as possible, such punishments nevertheless are subject to limits. The threat of a severe punishment will deter breach and support higher cartel profits. But the size of such punishment threats is limited by the restriction that the threats be credible. The requirement of credibility arises from the failure of courts to enforce any part of a collusive agreement. Collusive agreements must not only include provisions to restrict competition (for example, by raising prices); they must also include provisions on how to punish. Punishments must be credible because courts will refuse to enforce either type of agreement-just as they refuse to remedy failures to restrict competition, they will not remedy failures to punish. Punishments thus are used to make the competitive restrictions self-enforcing; the requirement of credibility makes the provisions to punish self-enforcing.

While extremely severe punishment threats will be in each cartel member's interest before any breach, for such threats to be credible it must remain in each firm's interest to carry out the punishment once a breach actually occurs. ${ }^{30}$ It is important to stress that this requirement of credibility must hold independently for each individual firm. For a punishment threat to be credible, each firm must decide, given that the other firms will punish, that punishing is in its best interest-in other words, is profit-maximizing behavior. ${ }^{31}$

29. The possible profits from breach might have other determinants that cause them to diverge from the upper bound in equation (2). If, for example, the breaching firm faces constrained capacity at the collusive level of production, it would not be able to capture the industry's entire demand and the profits from breach would accordingly be reduced. See infra notes $39-41$ and accompanying text.

30. For example, a threat to disclose publicly a trade secret known only to all cartel members if there is a breach would not be credible because such disclosure might irreversibly impair the cartel's ability to price above the competitive level. For general examinations of credibility, see Dixit, Recent Developments in Oligopoly Theory, $72 \mathrm{Am}$. Econ. Rev. (Papers \& Proceedings) 12, 13-14 (1982); Schelling, An Essay on Bargaining, 46 Am. Econ. Rev. 281 (1956).

31. In a game theory model of collusion, firms are the "players," whose choices to 
In the example of equation (2), ${ }^{32}$ the most direct way for a cartel to punish breach is to lower the cartel price in subsequent periods. Lowering the post-breach price would lower the breaching firm's future profits. The loss to individual breaching firms subjected to this punish-

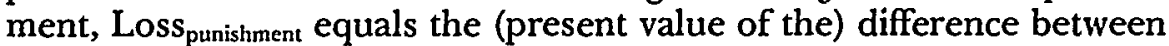
the continued cartel profits and these lower post-breach profits. The cost of the punishment to the breaching firm equals these foregone future profits. Indeed, in an industry with constant unit costs of production, the most severe credible punishment would be for every firm in the industry to charge the zero-profit competitive price. ${ }^{33}$

Such a punishment threat is credible because, even after breach, no individual firm has an incentive to deviate from the punishment price. Given that the other firms in the market charge the competitive price, no firm could sell any output at a higher price. ${ }^{34}$ More severe punishments (charging sub-competitive prices, for example) are not feasible, because the breaching firm could simply cease production and thereby avoid sustaining a loss.

This zero-profit punishment represents a structural upper-bound

punish or not punish represent different "strategies" for playing the "game." From the point of view of a single firm, a "Nash equilibrium" for such a game consists of a set of strategies from which individual players have no incentive to deviate. See G. Owen, supra note 10 , at 6 . The criterion for credibility formally defines such a Nash equilibrium. Credible punishments must therefore be Nash equilibrium strategies.

32. See supra notes $22-27$ and accompanying text.

33. "Zero-profit" is used here and throughout in the academic sense that firms earn only the competitive (market rate) return on their investments with no added rents or "economic profits." See R. Lipsey \& P. Steiner, Economics 199 (4th ed. 1975).

34. This zero-profit punishment is an example of a Nash equilibrium for the pricing game, developed by Bertrand in 1847, in which firms punish by lowering price. See J. Friedman, Oligopoly and the Theory of Games 38-39 (1977). However, when firms punish by raising output instead of lowering price, as first analyzed by Cournot in 1838, positive punishment profits are possible. See id. at 35-37. This is because the Nash equilibrium for the Cournot quantity game yields a super-competitive price.

Because Cournot profits are higher, Cournot quantity punishments are accordingly less severe than Bertrand pricing punishments, and credible self-enforcement is more difficult to achieve. However, while quantity games are more profitable, theory suggests that firms cannot choose between the quantity and pricing games. Instead, structural characteristics of the industry make either quantity or price competition more likely. Specifically, capacity constraints have been found to induce quantity competition. See Kreps \& Scheinkman, Quantity Precommitment and Bertrand Competition Yield Cournot Outcomes, 14 Bell J. Econ. 326 (1983). The Cournot quantity game is therefore analyzed with the discussion of capacity constraints. See infra notes 39-41 and accompanying text.

The Nash equilibrium of the Cournot quantity game also clarifies the notion of collusion used in this Article. Since even a Nash equilibrium for the Cournot game played only once yields positive profits, the ability to punish is not a necessary condition for super-competitive pricing. But credible punishments are necessary to support "collusion." Collusion as used in this essay refers then to agreements that yield greater profits than any single-period Nash equilibrium. See Abreu, Extremal Equilibria of Oligopolistic Supergames, $39 \mathrm{~J}$. Econ. Theory 191, 191-92 (1986) (using this definition for collusion). 
benchmark. ${ }^{35}$ Maybe the most striking feature of this pricing punishment is that the punishing firms, in exacting the punishment, are hurt just as much as the firm that breached the collusive agreement. Game theory tells us that such punishment threats can be credible if each firm believes that its competitors will punish. ${ }^{36}$ Nevertheless, a cartel may have difficulty creating such beliefs in large part because the pricing punishment is so damaging to the cartel's rank and file. Cartels thus will strive to construct more efficient punishments-that is, punishments in which the breaching firms will be forced to absorb a greater proportion of the punishment cost than the punishing firms. For example, if the cartel has operated by dividing the market into exclusive geographical territories, a targeted punishment might consist of selective price cuts to the breaching firm's territory. ${ }^{37}$

Punishments that are targeted to hurt the breaching firm more than the punishing firms are, therefore, likely to be more credible because the cartel can more easily establish the belief that the punishment will be exacted. Targeted punishments can be made even more credible if non-breaching firms that fail to punish run the risk of being punished themselves in subsequent periods. ${ }^{38}$

35. Setting the cartel price to the competitive price represents, it should be stressed, the most severe punishment per period, but does not indicate the most severe length of punishment. Some pure game theory models generate punishments of this type that continue indefinitely. See, e.g., Rotemberg \& Saloner, supra note 27, at 398. However, in a world with uncertainty, cartels will fear being locked into punishment strategies of infinite length-even if such a threat ex ante deters more chiselling - and therefore will need to agree on the length of time that a punishment will be inflicted. Other models provide incidences of punishments of limited length under conditions of uncertain demand. See, e.g., Green \& Porter, Noncooperative Collusion under Imperfect Price Information, 52 Econometrica 87 (1984); Porter, A Study of Cartel Stability: The Joint Executive Committee, 1880-1886, 14 Bell J. Econ. 301 (1983) [hereinafter Porter, Bell] (estimating length of punishment); Porter, Optimal Cartel Trigger Price Strategies, $29 \mathrm{~J}$. Econ. Theory 313 (1983).

If there are the same fixed costs of production in every period, the optimal punishments become extremely complicated, cf. Dasgupta \& Maskin, The Existence of Equilibria in Discontinuous Economic Games, 2: Applications 8-13 (London School of Economics, June 1982) (analyzing analogous fixed capacity game). Breaching firms could not be subjected to punishments in which they expected to lose money because these firms would choose instead to exit the industry or not to produce.

36. Indeed, history provides examples of extreme price wars. See infra note 125.

37. See, e.g., FTC v. Cement Institute, 333 U.S. 683, 710 (1948) (describing punishment of cement cartel that involved "selling cement in a recalcitrant price cutter's sales territory at a price so low that the recalcitrant was forced to adhere to the established [cartel] prices").

38. This punish-or-be-punished inducement has an analog in the codes of legal ethics, in which failure to report infringements of the code subjects a nonreporting lawyer to discipline as well. See Model Rules of Professional Conduct Rules 8.1 (b), 8.3 (1983); Model Code of Professional Responsibility DR 1-101(B), 1-103 (1977).

The dichotomy between targeted and non-targeted punishment has an analog in game theory. Both targeted and non-targeted punishments still must produce Nash equilibria in order to satisfy the requirement of credibility. See supra note 31 and ac- 
The next Part extends this simple model of cartel punishment not only by examining structural characteristics that limit the size of credible price punishments, but also by examining ways that cartels can punish other than by cutting price. The goal is to show both that the extreme pricing punishment of this section will often not be credible, and that other credible, and sometimes targeted, punishments may be available in its stead.

\section{Identifying Structural Aspects of Punishment}

This section presents and analyzes several factors that can influence the magnitude of a cartel's credible punishment threat. It shows how the pricing punishments of the previous section can be limited by capacity constraints and product differentiation. Additionally, many other types of nonprice punishments are identified, with a discussion of their availability in specific industries.

\section{A. Limits to Punishment Pricing}

The elementary relationship between price and demand informs our analysis of punishment pricing. In order for cartel firms to achieve the zero-profit punishment price, they must be able to increase output sufficiently to drive the price down to the competitive level. ${ }^{39}$ Anything that limits cartel firms' ability to produce will limit their ability to punish.

Capacity constraints therefore will directly limit a cartel's ability to punish if the industry does not have the capacity to produce the competitive output. ${ }^{40}$ In this situation, even with the most severe cartel

companying text. Non-targeted punishments are "single-period" Nash equilibria because they satisfy the requirements for a Nash equilibrium on a period-by-period basis. More specifically, non-targeted or "single-period" punishments, such as setting a zeroprofit cartel price, are credible when no firm has an incentive to deviate from punishment, looking at the payoffs of that single period alone.

Targeted punishments, in contrast, are "multiperiod" Nasb equilibria, because they can be credible even if firms have single-period incentives not to punish. Credibility can be established dynamically in such a case if a firm's failure to punish makes it subject to punishment in subsequent periods. For other examples of targeted punishments, see infra text accompanying notes 61-62 (exclusive dealing); 75 (exchange agreements); see also Abreu, supra note 34, at 197-220 (describing for the first time optimal multiperiod punishments).

Note that even single-period punishments can be inflicted for multiple periods if cartel members agree originally to repeat the punishments for a specific number of time periods. For example, if the zero-profit punishment of equation (2) is credible, a cartel could agree to punish breach by going to the competitive price for six months. Sec supra note 35 .

39. For a discussion of when quantity competition is more likely than price competition, see supra note 34 . If the punishing firms charged the competitive price but pro. duced less than the competitive output, there would be excess demand, which could enable the breaching firm to sell goods at a super-competitive price.

40. Recall, however, that if the breaching firm is capacity constrained, the profits 
punishment, a breaching firm will still earn more than the competitive zero-profit amount while being punished. Thus, the existence of capacity constraints among nonbreaching firms can exert a pro-competitive influence on an industry. ${ }^{41}$

This analysis also indicates that inventories might be held in part as a punishment threat. When capacity constraints limit the supportable amount of collusion, firms may agree to hold inventory solely for the purpose of deterring price chiseling. ${ }^{42}$

Finally, product differentiation will reduce the severity of pricing punishments. ${ }^{43}$ If products are differentiated, rivals will be able to sell at different prices and even competitive pricing by rivals will not drive a breaching firm's profits to zero. The most severe credible punishments in markets with product differentiation therefore generally will give the breaching firm positive profits. ${ }^{44}$ Differentiation has traditionally been modeled to affect only the ability to collude by making it more difficult to reach agreement and detect breach, ${ }^{45}$ but, as the analysis here indicates, it can reduce the ability to punish breach as well. ${ }^{46}$

from breach will be reduced. Because industry-wide capacity constraints can reduce both the prizes and punishments of price chiseling, it is impossible to label them categorically as pro- or anti-competitive. In industries where the amount of unused capacity differs among firms, the firms with the most excess capacity not only have the most to gain by breaching the collusive agreements, but also paradoxically are the ones most able to punish other breachers. A firm that is producing at capacity under a collusive regime can neither gain by prior chiseling nor punish other chiselers.

41. The competitive impact of capacity constraints is formally modeled in B. Bernheim \& M. Whinston, Multimarket Contact and Collusive Behavior (Apr. 1986) (unpublished manuscript on file at the Columbia Law Review); Rotemberg \& Saloner, supra note 27, at 392-98; see also Brock \& Scheinkman, Price Setting Supergames with Capacity Constraints, 52 Rev. Econ. Stud. 371, 371 (1985) (examining use of "industry capacity in enforcing collusion"); Saloner, Excess Capacity as a Policing Device, 18 Econ. Letters 83, 83 (1985) (dominant firms might invest in excess capacity to discipline competitors).

The most counterintuitive application of this theory is found in Rotemberg \& Saloner, Quotas and the Stability of Implicit Collusion (M.I.T. Department of Economics Working Paper No. 419, May 1986). The authors demonstrate how import quotas can promote competition. Quotas are normally thought to facilitate a division of the market and therefore to promote collusion. Rotemberg and Saloner show, however, that imposing quotas can limit the credible cartel punishment in response to breach and consequently increase competition. Id. at 32 .

42. See Rotemberg \& Saloner, Strategic Inventories and the Excess Volatility of Production 1 (M.I.T. Department of Economics Working Paper No. 391, Apr. 1985).

43. That consumers differentiate among products implies that the products are not perfect substitutes.

44. See Salop, Monopolistic Competition with Outside Goods, 10 Bell J. Econ. 141, 148 (1979) (presenting model in which even without collusion, firms in industries with product differentiation earn positive profits).

45. See, e.g., R. Posner \& F. Easterbrook, supra note 2, at 337.

46. Product differentiation may also reduce the profits from breach, so as with capacity constraints, see supra note 40 , the specific context of differentiation will determine whether self-enforcement is enhanced or not. 


\section{B. Nonprice Punishments}

While most commentators have focused solely on the availability of pricing punishment, ${ }^{47}$ cartels may have numerous nonprice instruments that can influence the level of punishments and ultimately the ability to collude. These instruments conveniently can be divided into those that affect demand and those that affect cost.

1. Punishments that Reduce Demand. - The pricing punishment lowers profits by reducing the demand for the breaching firm's products. But price is not the only strategic factor that influences consumer demand. Firms may also compete for consumers on the basis of several types of quality (by offering faster delivery, more reliable products, or a broader selection). A cartel could punish breaches of a cartel agreement ${ }^{48}$ by reverting to the competitive level of such nonprice variables. Again the size of these punishments would be limited by the notion of credibility. But as with pricing punishments, ${ }^{49}$ reverting to the competitive level of quality will be credible, ${ }^{50}$ because if all other firms are behaving competitively, no individual firm will have an incentive to deviate.

Advertising is an important, and in some ways unique, example of how firms attempt to compete for customers on a nonprice basis. ${ }^{51} \mathrm{But}$ what do advertising punishments look like? If a cartel decides to punish breaches by reverting to more competitive advertising behavior, will it punish by advertising more or less than the collusive level? The answer is not intuitively clear. This is because the advertising of a single firm may not only win over the customers of its competitors, but may also induce new demand for the product in general. To the extent that firms advertise to increase their relative market share (the market-share effect), ${ }^{52}$ competition would lead to more advertising than collusion. But one firm's advertising can also increase other firms' demand (the spillover effect). ${ }^{53}$ Since competitive firms do not take account of how their advertising benefits their competitors, competition might lead to

47. See, e.g., Green \& Porter, supra note 35.

48. Notice that breaches now might not only involve price chiseling, but chiseling along other competitive dimensions as well. Cf. National Macaroni Mfrs. Ass'n v. FTC, 345 F.2d 421, 423, 427 (7th Cir. 1965) ("agreements ... to fix and determine the quality of macaroni" are per se illegal).

49. See supra notes 20-27, 32-37 and accompanying text.

50. In game theoretic terms, credibility implies that the punishment strategies are single-period Nash equilibria. See supra notes 31,38 .

51. Schmalensee, Advertising and Market Structure, in New Developments in the Analysis of Market Structure 373, 373-74 (J. Stiglitz \& G. Mathewson eds. 1986).

52. Advertising comparison taste tests (e.g., Coca-Cola versus Pepsi) may have the primary effect of increasing the market share of the advertiser at the competitor's expense. See Schmalensee, supra note 51 , at 386.

53. Telser, Advertising and Competititon, 72 J. Pol. Econ. 537, 537 (1964). For example, when a beer brewer advertises on a hot summer day, the demand for other "refreshing" drinks may rise as well. See F. Scherer, supra note 1, at 386. 
less advertising than collusion. The tension between these two effects is analyzed in a simple model in the Appendix.

The results of the model in the Appendix indicate that punishment can either increase or decrease the collusive level of advertising, depending on the relative sizes of the spillover and market-share effects. ${ }^{54}$ When the spillover effect dominates, a cartel will punish by advertising less. ${ }^{55}$ When the market-share effect dominates, a cartel will punish by advertising more. In either case, however, the punishment will be credible. ${ }^{56}$

Identifying actual instances of punishment is difficult because advertising punishments can require either increasing or decreasing the collusive level of advertising. Moreover, as shown in the Appendix, if the spillover and market-share effects cancel each other out, the collusive and competitive amounts of advertising will be the same, and advertising punishments will not be possible. The presence of a spillover effect makes advertising competition unique, because other demandside variables have only the market-share effect. ${ }^{57}$ When there is only the market-share effect, punishment will unambiguously imply increased expenditures.

2. Punishments that Increase Cost. - Credible punishment can also emanate from the supply side of the market equilibrium by increasing the costs of a breaching firm.

54. In the absence of product differentiation, homogeneous or generic products are most likely to have a predominant spillover effect because advertising will only be able to increase total market demand for the product and not give individual firms an advantage. F. Scherer, supra note 1, at 386. "[N]o individual orange grower has an incentive to advertise ... since ... advertising would probably not shift much business toward one particular firm and away from other growers. ... But the Florida Citrus Commission, representing many growers, has a definite incentive to promote the sale of oranges generally ...." Id. at 387 .

55. In some markets, firms might respond by targeting advertising to specific consumer groups to reduce the demand for a breaching firm's products.

56. Because the punishments are single-period Nash equilibria, they are by definition credible. See supra notes 31,38 .

57. For example, if Budweiser begins producing a better tasting beer, the demand for other beers will not increase.

Investments in research and development might be modeled either as increasing the quality of a firm's product or as decreasing a firm's costs. To the extent that other firms benefit from the newly discovered information of their rivals, there may be supplyside spillover effects from research and development. The spillover effect in general will result whenever a firm's actions result in public goods upon which its free-riding competitors can benefit. Spence, Cost Reduction, Competition and Industry Performance, in New Developments in the Analysis of Market Structure, supra note 51, at 475, 476, 478 (when "there are substantial spill-overs . . . a significant part of the cost-reducing effects of a single firm's $R \& D$ accrue to other firms"). Thus, extending the model of the Appendix, collusive industries would spend more or less on research and development than a competitive industry depending on the relative sizes of these competing effects. Analyzing specific industries, enforcement agencies or courts could measure the relative magnitudes of the spillover and market share effects to predict whether punishments would entail increased or decreased expenditures. 
a. Raising Rivals' Costs. - Steven Salop and others have recently advocated the notion that a firm could credibly undertake a number of activities that would have an exclusionary effect by "raising rivals' costs." 58 For example, by executing exclusive dealing contracts with suppliers of an industry input, a firm might raise the costs of rivals that are forced to seek alternative sources of supply. ${ }^{59}$ Raising competitors' costs with such nonprice behavior is much more credible than price predation, because the predatory firm may be able to profit immediately by increasing its price. ${ }^{60}$

The ability to raise competitors' costs depends on a number of structural characteristics of the suppliers' market. Capacity in the suppliers' market must be limited, and entry barriers must be sufficiently high so that when part of the suppliers' output is foreclosed, the marginal cost of rivals purchasing the suppliers' output rises.

The ability to raise the costs of other firms can be used as a collusive practice as well. Where supply conditions allow exclusive dealing contracts to increase rivals' costs, a cartel could use the practice as a punishment threat. Prior to breach by any cartel member, colluding firms would produce a restricted output at the lowest cost possible and therefore would not execute exclusive dealing contracts solely for the purpose of raising other firms' costs. However, if a cartel member breached the collusive agreement, the cartel could credibly punish by raising the breaching firm's cost. At a minimum, the credible punishment could consist of resorting to the competitive number of exclusive supply contracts with suppliers. ${ }^{61}$ But it may be possible for the cartel to target a punishment more carefully so that it disproportionately af-

58. See Krattenmaker \& Salop, Anticompetitive Exclusion: Raising Rivals' Costs to Achieve Power Over Price, 96 Yale L.J. 209 (1986) [hereinafter Krattenmaker \& Salop, Yale]; Krattenmaker \& Salop, Competition and Cooperation in the Market for Exclusionary Rights, 76 Am. Econ. Rev. (Papers \& Proceedings) 109 (1986); Salop \& Scheffman, Raising Rivals' Costs, 73 Am. Econ. Rev. (Papers \& Proceedings) 267 (1983).

59. See generally R. Posner \& F. Easterbrook, supra note 2, at 725-902 (discussing exclusive dealing and related exclusionary practices). Such exclusionary practices have been prohibited. See, e.g., Aspen Skiing Co. v. Aspen Highlands Skiing Corp., 472 U.S. 585 (1985); Klor's, Inc. v. Broadway-Hale Stores, Inc., 359 U.S. 207 (1959).

60 . In contrast, price predation requires firms to forego current profits on the hope that, after rivals are driven from the industry, monopoly profits will ensue in the future. Several authors have suggested that the circumstances in which price predation will be a rational (i.e., profit-maximizing) behavior are at best extremely rare. See, e.g., Easterbrook, Predatory Strategies and Counterstrategies, 48 U. Chi. L. Rev. 263, 268-69 (1981). The Supreme Court has recently moved toward accepting these arguments. See Matsushita Elec. Indus. Co. v. Zenith Radio Corp., 106 S. Ct. 1348 (1986) (upholding dismissal of predatory pricing cases; stressing unlikelihood of successful predation).

61. Under competition, firms might individually have an incentive to raise rivals' costs for competitive advantage-but if all firms undertake this strategy all costs would be raised and no competitive advantage would ensue. Society, however, might be disadvantaged because the competitive price would reflect these added costs of competing for exclusionary rights. 
fects the breaching firm. Nonbreaching firms could gang up on a breaching firm by collectively tying up its sources of supply-such a punishment might be relatively cheap for individual punishing firms, but drastically expensive for the punished firm left without access to any suppliers. Such a punishment could be made credible, because if any punishing firm refused to take part, it would then also become subject to the same punishment. ${ }^{62}$

Indeed, collusive punishments of this sort are more likely to occur than exclusionary practices, because punishments may be credibly undertaken even when they reduce the punishing firms' profits. ${ }^{63}$ Moreover, while exclusionary strategies must be aimed at raising rivals' marginal cost (so that rivals will increase their output price), ${ }^{64}$ punishment strategies to support collusion can be aimed at fixed or overhead costs as well. ${ }^{65}$

This analysis might be applied to a number of other tactics that could credibly raise competitors' costs, including price squeezes, "inducing input suppliers to discriminate against rivals, lobbying legislatures or regulatory agencies to create regulations that disadvantage rivals, commencing research and development and advertising wars, and adopting incompatible technologies."66 These supply-side punishments all stem from actions that the cartel undertakes after a breach is detected. The following analysis looks at actions a cartel can take before breach has occurred in order to make supply-side punishments more severe.

62. See supra note 38 and accompanying text.

63. Krattenmaker and Salop limit the credible exclusionary use of raising competitors' costs to situations where "the acquiror of the exclusionary right has gained power to raise its price because its acquisition has significantly raised its competitors' costs." Krattenmaker \& Salop, Yale, supra note 58, at 252. In the punishment context, however, this restriction is inapposite. In most punishment equilibria the punishing firms' profits decrease; therefore even if the punishing firms (which acquire exclusionary rights) do not gain power to raise price, this punishment strategy can still be credible. See supra note 31 .

64. See Krattenmaker \& Salop, Yale, supra note 58, at 266 ('“b]ecause established firms' prices in the sbort run depend on short run incremental costs, then only those exclusionary rights that increase short run incremental costs" are credible).

65. To deter collusion, punishments need only reduce the breaching firm's profits. Since either higher fixed or marginal costs reduce profits, fixed-cost punishments can also be effective. See Krattenmaker \& Salop, Yale, supra note 58, at $250 \mathrm{n} .129$ (distinguishing fixed and marginal costs).

66. Salop \& Scheffman, Cost-Raising Strategies 3 (FTC Bureau of Economics Working Paper 146, 1986). Note, however, that lobbying legislatures or regulatory agencies may be protected under the Noerr-Pennington Doctrine as exercising the right to petition the goverument. See, e.g., United Mine Workers v. Pennington, 381 U.S. 657 (1965); Easteru Railroad Presidents Conf. v. Noerr Motor Freight, Inc., 365 U.S. 127 (1961); see also California Motor Transport Co. v. Trucking Unlimited, 404 U.S. 508 (1972) (recognizing similar right to petition the courts, but refusing to protect "sham" litigation). 
b. Hostage Exchanges. - Oliver Williamson has analyzed situations in which firms that traded goods might exchange hostages (for example, by posting bonds, or creating sunk costs) to keep each other from breaching their agreement. ${ }^{67}$ Similar hostage mechanisms that facilitate horizontal cartel agreements by increasing the ability to punish breach could develop. Williamson's starting point was that vertical agreements might be prohibitively expensive to enforce in the courts; ${ }^{68}$ horizontal cartel agreements are analogous because they are per se unenforceable. ${ }^{69}$

To extend Williamson's analysis to the punishment context, it is necessary to identify the specific types of assets that cartel firms could use for horizontal hostages. The essence of a hostage exchange is that cartel members must invest in assets whose value could be adversely affected by other firms. This implies that the investments must be irreversible or "sunk," and that often the assets will be, to use Williamson's term, "transaction specific" so that the asset's value if not used with cartel members is lessened. ${ }^{70}$

At first, it would seem that the possibility for horizontal hostage exchanges is relatively restricted because rival firms lack the technological contact that characterize many vertical relationships. ${ }^{71}$ In fact, horizontal rivals normally do not exchange goods. But there remain structural settings where credible hostage exchanges may facilitate collusive agreements.

i. Product Exchanges. - While trade among rivals is the exception, there are instances "whereby one rival will sell product to another on a short-term, gap-filling basis so as to provide temporary relief against unanticipated product shortfalls (occasioned by either demand or supply changes)."72 For example, the major petroleum firms routinely exchange oil. ${ }^{73}$ Williamson has suggested that such exchanges could be efficient in industries characterized by significant economies of scale

67. O. Williamson, The Economic Institutions of Capitalism 163-206 (1985); Williamson, Credible Commitments: Using Hostages to Support Exchange, $73 \mathrm{Am}$. Econ. Rev. 519 (1983); see also Klein, Crawford \& Alchian, Vertical Integration, Appropriable Rents, and the Competitive Contracting Process, 21 J.L. \& Econ. 297 (1978) (vertical integration may be structural alternative to unenforceable vertical contracts); Klein \& Leffler, The Role of Market Forces in Assuring Contractual Performance, $89 \mathrm{~J}$. Pol. Econ. 615 (1981) (discussing extra-legal contractual protection).

68 . Williamson, supra note 67 , at 526-28.

69. See United States v. Socony-Vacuum Oil Co., 310 U.S. 150, 223 (1940).

70. Williamson, supra note 67 , at 522 . Williamson suggests that specialized dies, which cannot be retooled for other projects, are an example of transaction-specific assets. Id. at 524.

71. For example, buyers and sellers must often make transaction-specific investments to deal efficiently with each other.

72. Williamson, supra note 67 , at 528 .

73. See, e.g., In re Exxon Corp., 98 F.T.C. 453, 457 (1981) (detailing unsuccessful government challenge of the practice); In re Weyerhaeuser Co., 49 Antitrust \& Trade Reg. Rep. (BNA) 1081, 1085-86, 1089 (1985) (examining similar "exchange agree- 
and separate geographic markets. Individual firms in different geographic markets might invest in more capacity to supply most efficiently any temporary demand fluctuations in their home market. This extra capacity represents dedicated assets which are "put in place contingent upon particular supply agreements."74

Cartel members could inflict targeted punishments under such circumstances by refusing to exchange oil with a breaching firm. The breaching firm would be punished by its creation of unused excess capacity and by not being able to use its capacity to supply unanticipated short-falls in other markets. ${ }^{75}$

ii. Joint Ventures. - Firms producing competing goods at independent plants might form a joint venture as a means of increasing punishment threats and therefore the amount of self-enforcing collusion. A joint venture member, for example, might breach a cartel agreement by producing more than its cartel quota at its independent plant. The cartel might then use its voting power deliberately to mismanage the joint venture. ${ }^{76}$ Because the value of capital contributions of the cartel members will depend on the joint venture's economic performance, mismanagement will constitute a non-targeted punishment that would lower the value of the breaching firm's capital contribution (as well as lowering that of the punishing firms). While this analysis is no more than suggestive, it might be an additional tool to assess, for example, the probable competitive effect upon social welfare of the General Motors/Toyota joint venture. ${ }^{77}$

iii. Shared Markets. - When firms compete in some markets and not in others, there may be advantages to establishing passive outposts

ments" in paper pulp industry); 5 The State of Competition in the Canadian Petroleum Industry 49-54 (R. Bertrand, coordinator 1981).

74. Williamson, supra note 67 , at $526,531-32$.

75. Id. at 526,535 (refusing to exchange oil would result in significant excess capacity of dedicated assets). A refusal to deal would not be actionable as a breach of contract if cartel members contemplating using such refusals as a punishment device were purposely not to enter long-term exchange projects.

In a similar spirit to such product exchanges, one could imagine a variant of the celebrated case, United States v. Socony-Vacuum Oil Co., 310 U.S. 150 (1940), in which the dominant firms could punish breach by refusing to continue to buy the "distress oil" of their individual "dancing partners."

76. When the joint venture is run as a corporation separate from the co-investors, state corporate law protects the co-investors from actions that profit one at the expense of others. See D. Vagts, Basic Corporation Law 237 (2d ed. 1979) (discussing duty of loyalty). Actions that generally reduce the value of the joint venture, however, will be largely immunized by this business judgment rule. See Casey v. Woodruff, 49 N.Y.S.2d 625, 642-43 (Sup. Ct. 1944).

It may be difficult to make the threat of joint venture punishment credible because the punishing firm may be destroying its own sunk investments at the same time.

77. But see In re General Motors Corp., 103 F.T.C. 374 (1984) (not discussing punishment or disciplinary effect of jointly sunk assets). See generally United States Department of Justice, Antitrust Guide Concerning Research Joint Ventures (1980) (failing to consider possible use of joint ventures as hostages to support collusion). 
in rivals' territory. Suppose, for example, that there are three separate markets for a particular product and that firm $A$ dominates the first market, firm $B$ dominates the second market, and both $A$ and $B$ supply the third market. If the firms wish to facilitate collusion in the shared market (the third market), it might be possible to approximate a hostage exchange by having each firm commit to a small level of entry upon the other firm's turf. Far from being a pro-competitive act, sinking a small amount of fixed capacity in the other firm's market could credibly increase the cost of breach. For example, if firm $A$ invests sunk $\operatorname{costs}^{78}$ to establish a relatively small capacity in the second market, it could be vulnerable to predation by firm $B$ in that market. Firm $B$ could then respond to price chiselling by firm $A$ in the shared market by reducing its price in the second market. If there are significant economies of scale ${ }^{79}$ in this industry, the firm with the higher output-firm $B$-will be able to exploit these economies and produce at a lower unit cost in the second market. ${ }^{80}$ Such predation might be possible because firm $B$ could lower its price below the cost of firm $A$ while still making a profit. $^{81}$

These examples of hostage exchanges are meant to be illustrative, not exhaustive. The goal of this hostage exchange analysis is similar to the goal of this Part-to demonstrate that cartels may have many more instruments to punish credibly than normally recognized, and that the availability of these instruments will often depend on the structural conditions of demand and supply extant in the industry.

\section{The Structural Impact of Interest Rates}

The previous Part demonstrated how cartels could influence many of the methods of punishment: cartel members, for example, could hold larger inventories, build more capacity, or alter advertising levels. Because the interest rate cannot be determined by firm behavior, this Part considers separately how the interest rate affects the feasibility of collusion.

78. See W. Baumol, J. Panzer \& R. Willig, Contestable Markets and the Theory of Industry Structure 280-81 (1982) (sunk costs, such as investment in an automobile assembly line, "cannot be eliminated, even by total cessation of production").

79. See F. Scherer, supra note 1 , at 81 .

80. This example assumes that transporting goods between markets is uneconomical.

81. This example illustrates how cartels might be willing to endure substantial costs (here, in the form of inefficient low-volume production) to make the cartel agreement self-enforcing. See also infra notes 128-30 and accompanying text (firms may incur inefficient marketing costs as part of a targeted punishment strategy). This cost of cartelization represents wasted resources and is akin to the social cost of monopoly. See Posner, The Social Cost of Monopoly and Regulation, 83 J. Pol. Econ. 807, 817-21 (1975).

For a related analysis of self-enforcing collusion in overlapping product markets, see B. Bernheim \& $M$. Whinston, supra note 41 , at 3-5. 
In deciding whether to chisel on a cartel price, firms necessarily weigh current price-cutting profits against future punishment costs, so the rate at which future punishments are discounted will affect the cartel's ability to collude. The pivotal importance of the interest rate in determining the size of punishment can be seen by returning to the simple model of Part I. ${ }^{82}$ Assuming that an industry faces stable demand and cost conditions in the future and that the cartel agreement remains in effect indefinitely, the cartel members will earn Profit cartel $_{\text {in }}$ each future period. The present discounted value of these future profits, $P D V$, is:

$$
\mathrm{PDV}=\frac{\text { Profit }_{\text {cartel }}}{r}
$$

where $r$ equals the rate of interest. ${ }^{83}$ If the optimal zero-profit pricing punishment is feasible, then the lost profits from punishment will exactly equal $P D V$. Moreover, if the maximum profits from breach, as shown in equation (2), ${ }^{84}$ are obtainable, then by substituting equations (2) and (3) into equation (1), we can derive that a breach will be deterred only if:

which, after simplifying, is:

$$
(\mathrm{N}-1) \text { Profit }_{\text {cartel }}<\frac{\text { Profit }_{\text {carrel }}}{r}
$$

$$
r<\frac{1}{N-I}
$$

This result ${ }^{85}$ is rather striking, because it implies an all-or-nothing outcome that depends solely on the interest rate ${ }^{86}$ and the number of firms in the industry. When the interest rate is small relative to the number of firms, perfect collusion will be self-enforcing. When the interest rate is relatively large, however, the foregone profits of punishment are discounted sufficiently so that no collusion is possible.

This razor-edge quality is lost, though, once we allow for changes in future demand or supply conditions. ${ }^{87}$ For example, if the demand

82. See supra notes $20-27,32-37$ and accompanying text.

83. Equation (3) is derived from:

$$
\operatorname{PDV}=\sum_{i=1}^{\infty} \text { Profit }_{\text {entel }}\left(d^{i}\right) \text {, where } d=\frac{1}{1+r}
$$

Equation (3) assumes that the cartel profits will last indefinitely. Solving this infinite sum yields the result of equation (3).

84. See supra note 23 and accompanying text.

85. Similar derivations can be found in B. Bernheim \& M. Whinston, supra note 41 , at 10-12; Rotemberg \& Saloner, supra note 27, at 393 .

86. The relevant interest rate will be the rate at which the person deciding whether to breach (usually the manager) discounts future dollars. A manager that acts in the shareholders' interests should treat this like any other investment decision, using the firm's risk-adjusted interest rates for various investment categories as a guide to action. See R. Brealey \& S. Myers, Principles of Corporate Finance 164-66, 172 (2d ed. 1984). But see infra note 98 and accompanying text (describing situations when managers might apply different interest rates).

87. Rotemberg \& Saloner, supra note 27 , at 395 , show how intermediate levels of collusion are possible for a range of interest rates when demand is allowed to fluctuate. 
in the industry is expected to be lower in the future, the profits from collusion, Profit $t_{\text {carel }}$ will be lower as well. Breaching firms will accordingly forego less future profits so that the supportable current collusion will also be reduced.

This analysis might be applied either across industries or across time. Differing interest rates across industries, for example, might contribute to different propensities for collusion in those industries. ${ }^{88}$ Moreover, under this analysis, the risk-averseness and myopia of managers becomes a pro-competitive force. Managers are often thought to discount future profits excessively when making investment decisions, worrying more about today's profits. ${ }^{89}$ Such myopia would lead managers to breach collusive agreements far more often than the diversified shareholder would prefer because the prospect of highly discounted punishments will not deter them.

Changes in interest rates might also create differing patterns of collusion within a single industry over time. This could shed light on Scherer's casual empirical observation that cartels seem to be the product of recessions while mergers seem to be the product of booms. ${ }^{90}$ If interest rates vary with the business cycle (that is, are pro-cyclical), ${ }^{91}$ then during recessions, interest rates would be lower and punishments would hurt more. The self-enforcement requirement of condition (1) would thus more likely be fulfilled during recessions, and enforcement should thus be increased in such periods. ${ }^{92}$

Finally, the foregoing analysis of interest rates can explain an interesting wrinkle in the recent demise of the Organization of Petroleum Exporting Countries (OPEC) cartel. As discussed above, the unexpected reduction in demand for oil that developed in the 1980 's ${ }^{93}$ could predictably make the prevailing cartel price from the 1970's unsupportable. One would expect in these circumstances that OPEC would have reduced the cartel price to eliminate incentives for breach.

It is at first surprising therefore that cartel participants suggested that, once chiseling had caused the spot price to drop, the cartel was unstable because it could not reestablish the price at a sufficiently high level. ${ }^{94}$ After all, a lower cartel price should have made the OPEC car-

Moreover, structural constraints, such as capacity constraints or speed of retaliation, may affect the size of either the profits from breach or the punishment. See supra notes 21-46 and accompanying text.

88. Industries face different rates of interest due to different risks and differences in the correlation of various industry returns with the systematic risk of the economy. See R. Brealey \& S. Myers, supra note 86, at 164, 172-73.

89. R. Reich, The Next American Frontier 140-72 (1983).

90. See F. Scherer, supra note 1, at 126-27 (mergers), 214-19 (cartelization).

91. See R. Lipsey \& P. Steiner, supra note 33, at 417.

92. This result is independently supported by a reduced demand effect in the business-cycle model of Rotemberg \& Saloner, supra note 27, at 395.

93. See Silk, Confronting New Oil Fears, N.Y. Times, Jan. 29, 1986, at D2, col. 1.

94. Cf. e.g., OPEC's Third-Quarter Production Target Too High to Stabilize Mar- 
tel more stable. This paradox can be explained by clarifying the relationship beween interest rates and punishment.

A major difference between OPEC and other cartels is that the member "firms" are countries. Some commentators have thought that OPEC countries had minimum revenue requirements that would not be met if the cartel price were too low. ${ }^{95}$ The effect of these revenue requirements on the incentive to breach can be expressed as a change in interest rates. In formal game-theoretic models, the interest rate represents the probability that the game will end in the next period. ${ }^{96}$ If the game ends, there can be no punishment. Thus, the expected punishment should be discounted by the probability that the game will end. For example, if there is a $10 \%$ chance that the game will end in the next period, firms will discount future punishments by $10 \%$ to calculate the expected punishments from breach. In the political context of OPEC, the analog to the probability that the game ends in the next period is the probability that the leaders lose the next election or that a revolution occurs. The revenue requirements then can be seen to influence directly this probability. Since oil revenues were used to finance stabilizing social programs, as the revenues declined the probability that "the game will end" increased. This stylized characterization is supported by several analysts and by the actual political turmoil that has followed the decline in price in many countries. ${ }^{97}$

Since oil-country revenues monotonically decrease with lower cartel prices, a low cartel price could have caused OPEC countries greatly to discount future punishment costs. For low cartel prices, even the small gains from price chiseling could outweigh the prospect of future punishment if the threat of a revolution or lost election made the rulers' interest rate sufficiently great. ${ }^{98}$ Thus, the combination of declin-

ket, Platt's Oilgram, Aug. 18, 1986, at 1 (market analyst argues that OPEC production quotas are too high to stabilize market at prices "high enough to secure OPEG countries' revenues").

95. Griffen, OPEC Behavior: A Test of Alternative Hypotheses, 75 Am. Econ. Rev. 954, 956 (1985).

96. See D. Fudenberg \& J. Tirole, Dynamic Models of Oligopoly 3-4 (Institute for Mathematical Studies in the Social Sciences Technical Report No. 428, Oct. 1983).

97. See, e.g., Kristof, Economic and Political Shifts Seen if Oil Price Fall Persists, N.Y. Times, Jan. 27, 1986, at A1, col. 2; Stockton, Fall in Oil Price is Called a Spur to Mexico Crisis, N.Y. Times, Feb. 10, 1986, at A1, col. 5.

The inverse relationship between oil revenue and the interest rate can more conventionally be seen for the OPEC members that are debtor nations. As oil revenues decline, the prospects of repayment fall, thus causing the country-specific risk to rise. See Gargan, Nigeria's Economy Faces New Burden, N.Y. Times, Jan. 27, 1986, at D1, col. 1 .

98. This analogy could be extended to the market for corporate control. Firm managers might have higher discount rates if they believe that the threat of a corporate takeover will increase if current profits decrease. See supra note 89 and accompanying text. Takeover threats might have the heretofore unnoticed pro-competitive effect of encouraging managers to breach collusive agreements. 
ing demand for oil and the impact of declining revenues on the interest rate could have made any collusive price by OPEC unsupportable.

This example illustrates the importance of interest rates to selfenforcement of cartel agreements. Since the profits from breach and the costs of punishment will normally accrue over time, firms will take account of the time value of money. Analyzing interest rates determines how much a punishment hurts. Indeed, for sufficiently high interest rates, collusion will become unsupportable as the discounted cost of future punishments will fail to deter breach. Thus, understanding this relationship between interest rates and self-enforcement can help policymakers predict when punishments are most likely to occur.

\section{Legally Enforceable, Disguised Punishments}

The thrust of the analysis to this point has been centered on cartel agreements that cannot be legally enforced-indeed such agreements are criminal ${ }^{99}$ - however, it is not surprising that cartels would try to incorporate disguised punishments in legally binding contracts to deter price chiseling. The incentives for such circumvention are great because the punishments in legally binding agreements are not restrained by the ex post credibility requirement. ${ }^{100}$ This Part briefly examines three ways a cartel might be able legally to contract to punish price chiseling. The first two mechanisms, meeting-competition and mostfavored-nation clauses, are commonly analyized as "facilitating practices."101 The third mechanism involves patent licensing as illustrated by United States v. General Electric Co. ${ }^{102}$

\section{A. Meeting-Competition Clauses}

A meeting-competition clause (MCC) is a contractual commitment by a seller not to be undersold for the life of a supply contract. ${ }^{103}$ Such agreements have avoided antitrust prohibition possibly because they are vertical agreements between buyers and sellers and not horizontal agreements solely among sellers. ${ }^{104}$ Nonetheless, as Salop and others

99. See 15 U.S.C. $\$ 1$ (1982).

100. See supra note 30 and accompanying text.

101. "Facilitating practices" are so named because they facilitate collusion. See, e.g., Salop, Practices that (Credibly) Facilitate Oligopoly Co-ordination, in New Developments in the Analysis of Market Structure, supra note 51 , at 265. Some of these practices can facilitate collusion by making it easier to reach agreement, and detect price chiseling. Id. at 269, 273. My purpose, however, is to focus on the practices that make it easier to enforce collusive agreements with credible punishments.

102. 272 U.S. 476 (1926).

103. See Salop, supra note 101, at 279. MCC have been employed in various industries. See, e.g., International Salt Co. v. United States, 332 U.S. 392 , 394 n.5 (1947); Salop, supra note 101 , at 287 n.37.

104. See J. Simons, Fixing Price with Your Victim: Efficiency and Collusion With Competitor Based Pricing Clauses 53-67 (Oct. 29, 1986) (unpublished manuscript on file at the Columbia Law Review) (arguing that in oligopolistic markets "competitor 
have shown, an MCC can credibly facilitate the maintenance of a cartel price. ${ }^{105}$

The anti-competitive impact of an MCC can be given a straightforward punishment interpretation. An MCC credibly commits rivals to reduce price in the face of price chiseling. The threat to reduce price is credible because its enforcement is ensured by third parties, the buyers. Ironically, the punishment threat is created by contracts with the very victims of the cartel. ${ }^{106}$ Although a monopsonist buyer would never have incentives to sign contracts that would ultimately hurt it and thus never sign an MCC contract, multiple buyers might have individual incentives to enter into MCC contracts. ${ }^{107}$ This is because, in a market with an established cartel, increased competition is itself a public good, the benefits of which individual buyers will not capture. Thus an MCC can credibly commit rivals to pricing punishments and thus entitle rivals to maintain a higher price than if there were no MCC.

\section{B. Most-Favored-Nation Clauses}

A most-favored-nation (MFN) clause is a contractual commitment by a seller not to sell to other buyers for a lower price for the life of a supply contract. ${ }^{108}$ Once a super-competitive cartel price is established, an MFN clause also acts to increase the costs of price cuts. Unlike an MCC, where the rivals are committed to punishing, the MFN clause is a credible commitment to self-punishment, enforceable by buyers. ${ }^{109}$

Of special interest are retroactive MFN clauses that rebate any future price decreases to a buyer. ${ }^{110}$ A firm considering breaching a cartel agreement by price chiseling now faces the prospect that it may have to rebate significant profits from the past if it breaches. The judicial enforcement of a retroactive MFN clause, therefore, can enable cartels

based formula pricing clauses," which include MCC, can violate the Sherman Act even in vertical contracts). See generally Clark, Price-fixing Without Collusion: An Antitrust Analysis of Facilitating Practices after Ethyl Corp., 1983 Wis. L. Rev. 887, 934-35 ("assessment of the impetus for including meet-or-release clauses . . . should help to determine whether, on balance, the use of the clause has positive or negative effects upon competition").

105. See Salop, supra note 101, at 279-82.

106. See J. Simons, supra note 104 , at $49-51$.

107. A buyer's refusing to enter MCC contracts would help make the entire market more competitive, but since each buyer cares only about its own purchase price, it may not forebear for the benefit of other buyers. Refusing to enter MCC contracts is thus a public good that benefits buyers in general, but which independent buyers might fail to refuse. See id.

108. See E.1. Du Pont De Nemours \& Co. v. FTC, 729 F.2d 128, 134 (2d Cir. 1984) (permitting use of most-favored-nation clauses).

109. Under certain conditions there is no disadvantage in being the first firm to introduce the clauses. See, e.g., Cooper, Price Protection Policies and Tacit Collusion, 17 Rand J. Econ. 377, 377 (1986) (discussing MFN clauses).

110. Salop, supra note 101 , at $274-75$. 
to circumvent the temporal restriction that punishments can flow only from reduced future profits. ${ }^{111}$ Here, price-chiseling can occasion the loss of past as well as future profits, making this one of the most severe punishments.

\section{Sham Patent Licensing Agreements}

Finally, consider the opportunities for including binding punishment threats in sham patent licenses. Such opportunities are illustrated in the General Electric/Westinghouse light bulb license. ${ }^{112}$ In 1912, General Electric granted to Westinghouse patent licenses for the manufacture and sale of light bulbs. The license required Westinghouse to maintain the price that General Electric charged for bulbs ${ }^{113}$ and to pay a royalty of two per cent of net sales-which rose, however, to 10 per cent if Westinghouse's net sales exceeded 15 percent of General Electric-Westinghouse total net sales. ${ }^{114}$

George Priest has suggested that the license agreement might have been used to fix price: "A royalty of 2 per cent indicates either that the patent was trivial and the parties were simply price-fixers, or that General Electric was distributing patent rents in return for an agreement to fix price and limit output."115 The increasing royalty is especially relevant to the issue of punishment. For if General Electric's patent were invalid and the license agreement were entered solely to facilitate collusion, then the escalating royalty would punish price-chiseling. Westinghouse would be deterred from giving secret price cuts in order to increase its output beyond the 15 percent market share that triggered the punishment royalty, which was five times higher.

\section{Policy Implications}

Policies that reduce the magnitude of credible punishments (or increase the profits from breach) will consequently reduce the amount of collusion. Thus, public policies should promote structural characteristics that constrain punishment. For example, courts might refuse to enforce MCC and MFN contracts where collusion is likely. ${ }^{116}$

111. See supra note 28 and accompanying text.

112. See United States v. General Elec. Co., 272 U.S. 476 (1926) (sustaining validity of patent license). The discussion here is derived from George Priest's original analysis of the case. Priest, Cartels and Patent License Arrangements, 20 J.L. \& Econ, 309, $340-49$ (1977).

113. See 272 U.S. at 479,482 .

114. See Priest, supra note 112 , at $345-46$ (citing record).

115. Id. at 346.

116. The United States could apply this analysis to help insure that OPEC does not revitalize. Simply stated, OPEC could be destabilized by giving individual producer nations greater incentives to breach the OPEC agreement. An optimal strategy of destablization would combine a mixture of carrots (to increase Profit irstrith $_{\text {in }}$ condition (1)) and sticks (to increase the costs of not breaching). For example, additional or renewed United States foreign aid to specific oil-producing nations could be conditioned on the 
But even if such characteristics are beyond policymakers' control, identifying the relationship between structure and punishment has relevance to policy. Judge Posner, for example, has advocated the use of structural information not only "to enable enforcers to concentrate their resources in markets where the resources are likely to be employed most productively" but also to aid in establishing actual "proof of collusion, explicit or tacit."117

Making punishment threats credible may often be quite complicated. Without explicit communication, reaching an understanding ${ }^{118}$ of what the punishment will be can be quite difficult. Therefore, appreciating the necessity of punishment can rationalize the law's current emphasis on communication-but at the same time can reveal that formal agreement is not necessary in all structural settings. ${ }^{119}$ Indeed, this analysis can refocus the debate between Posner and Turner on

excess production of oil. Linking economic development loans and the refinancing, so badly needed by some producer nations, to OPEC betrayal might be especially effective. After all, the need for oil revenues to service existing debts is what induced Nigeria and Venezuela to cheat in the first place. The International Monetary Fund has been conditioning loans for years on such factors as the borrower's fiscal deficit or money supply. Destabilization would simply condition aid on a different action of the borrowing state.

Such a policy is feasible. OPEC's recent instability demonstrates that several nations have chosen to chisel of their own accord-so the size of the prizes or punishments need not be great to make it in individual countries' interest to breach the cartel agreement. And only a few countries need to be so targeted in order to restore competition in the oil market.

Indeed, the presence of one or a few price cutting firms can have a dramatic procompetitive effect on a market-consider, for example, the impact of MCI on AT\&T's long-distance telephone rates. See MCI Communications v. American Tel. \& Tel. Co., 708 F.2d 1081, 1099 (7th Cir.) (one month after MCI announced plans for nationwide long distance service in selected cities, AT\&T sought permission to lower its long distance rates in many of those cities), cert. denied, 464 U.S. 891 (1983); MacAvoy \& Robinson, Winning by Losing: The AT\&T Settlement and Its Impact on Telecommunications, 1 Yale J. on Reg. 1, 9-14 \& n.52 (1983). More generally, government policymakers might consider undertaking single-firm interventions instead of market intervention (i.e., industry regulation) to correct or improve anticompetitive behavior. Even private firms have sometimes had incentives to create a competitive presence in upstream supplier markets or downstream customer markets. See, e.g., United States v. Columbia Pictures Indus., 507 F. Supp. 412, 419-20 (S.D.N.Y. 1980) (four major film studios claimed to enter joint venture in pay TV distribution to act as competitor to existing distributors with large market share).

117. R. Posner, supra note 2, at 55 (structural evidence permits "ambiguous conduct to be evaluated"). Posner advocates a two-stage approach to punishing collusion: "The first would involve identifying those markets in which conditions are propitious for the emergence of collusion; the second, determining whether collusive pricing in fact exists in such a market." Id.; see also supra notes 8-12 and accompanying text (discussing differences between explicit and tacit collusion).

118. See supra text accompanying note 11 .

119. Indeed, this is why the "finking" result of the prisoner's dilemma game never turns on whether the prisoners are allowed to communicate. See discussion supra note 17 and accompanying text. 
whether tacit agreements should be prohibited. ${ }^{120}$ Turner, who would legalize tacit collusion, seems to assume in his analysis that the profits from tacit collusion will be limited because there are no punishments. ${ }^{121}$ However, once we allow for the possibility that firms could tacitly agree on punishment threats as well as on a collusive price, more anticompetitive levels of collusion are possible. ${ }^{122}$ Thus, Posner's response to Turner ${ }^{123}$ becomes even more compelling when there is evidence of punishing behavior. While an enforcement agency might not be able to keep firms from pursuing their best interest given their understanding of how other firms will react, it can change the "given." By prosecuting tacit collusion where understandings of punishment are evident, courts can discourage such understandings from being established. ${ }^{124}$

Thus, identifying variables that might distinguish industries' ability to punish credibly cannot only aid enforcement targeting, but can also be a step in identifying after the fact whether punishments actually have been exacted. Evidence of actual episodes of punishment could then be used as direct evidence of cartel agreement. For example, the dramatic, short-lived price wars in the electrical equipment industry were persuasive evidence that a cartel existed. ${ }^{125}$

Because non-targeted punishments are more difficult for thirdparty observers to identify than targeted punishments, targeted punishments should be given special scrutiny. If a punishment consists of reverting to competitive behavior (such as the zero-profit punishment price of Part I $)^{126}$ then third parties will not be able to distinguish epi-

120. Compare R. Posner, supra note 2, at 42-55 (arguing that tacit collusion should create liability under $\S 1$ of the Sherman Act) and Posner, supra note 26, at 1562, 1563-93 (same) with Turner, The Definition of Agreement under the Sherman Act: Conscious Parallelism and Refusals to Deal, 75 Harv. L. Rev. 655, 657-73 (1962) (arguing that $\S 1$ should not reach tacit collusion).

121. See Turner, supra note 120 , at 666 . Turner's theory of "oligopolistic interdependence" seems to contemplate a Cournot quantity game in which firms earn profits without punishment threats. See supra note 34; see also R. Posner, supra note 2, at 74 (Turner's theory is "tantamount to arguing that oligopoly is a sufficient as well as necessary condition of tacit collusion.").

122. See supra notes $23-27$ and accompanying text.

123. See R. Posner, supra note 2 , at 74 (criticizing Turner's theory).

124. See id. at 74.

125. A period of dramatically successful collusion in the electrical manufacturing industry (1955-1959) was bracketed by two severe episodes of punishment. J. Herling, The Great Price Conspiracy: The Story of the Antitrust Violations in the Electrical lndustry 14 (1962) ("The famous 'white sales' in the electrical manufacturing industry was a fantastic price war that raged from late 1954 until September, 1955."); 1 R. Sultan, Pricing in the Electrical Oligopoly 71 (1974) ("Between 1959 and 1961 price levels in the turbine generator industry declined by more than 40 percent."). Punishing pricc wars have also been identified in the pre-Sherman Act railroad industry in Porter, Bell, supra note 35 , at $302-03$.

126. See supra notes $33-35$ and accompanying text. 
sodes of punishment from breakdowns of the cartel.127 Targeted punishments, however, are easily distinguished from competitive behavior. For example, in a market that a cartel has divided into geographic territories among firms, the targeted punishment of sending extra sales people into the territory of a breaching firm is especially visible as firms attempt to increase sales in the market with the lowest mark up.

This Article has identified many types of targeted punishmentsexclusive dealing, territorial targets, and product exchanges-but others may also be available. For example, in FTC v. Cement Institute, ${ }^{128}$ the Supreme Court explicitly described a targeted punishment involving basing point pricing: ${ }^{129}$

During the depression in the 1930's, slow business prompted some producers to deviate from the prices fixed by the delivered price system. Meetings were held by other producers; an effective plan was devised to punish the recalcitrants and bring them into line. The plan was simple but successful. Other producers made the recalcitrant's plant an involuntary base point. The base price was driven down with relatively insignificant losses to the producers who imposed the punitive basing point, but with heavy losses to the recalcitrant who had to make all its sales on this basis. ${ }^{130}$

It is a happy coincidence for society that such targeted punishments, the most credible form of punishment, are also the most readily identifiable. If enforcement agencies can drive out such targeted punishments, cartels will have to resort to the less visible, but less effective, non-targeted punishments: breaches of collusive agreements will be encouraged, and collusion thereby reduced.

127. For example, at this writing it is impossible to know whether OPEC is in a punishment phase or whether the collusive agreement has been replaced by competition. Compare Pauly, The Unmaking of an Oil Cartel: Commodity Price Fixing Schemes Inevitably Fail, Newsweek, Feb. 3, 1986, at 36 (attempt to control oil prices inevitably gave way to competitive market pressures) with lbrahim, OPEC Leaders Affirm Support for Price War, Wall St. J., Feb. 4, 1986, at 3, col. 1 (OPEC leaders attempt to re-assert authority of oil cartel by punishing renegade producers with even lower prices).

128. 333 U.S. 683 (1948).

129. In a "basing-point pricing system" sellers transport the good to the buyer's place of business and charge a "delivered price"-that is, a price that includes a charge for the transportation. Id. at 697 . Basing-point prices are calculated by determining the transportation charge as if all goods were shipped from a common base point even if the goods are shipped from a producer at a much closer location. A well-known early example is the "Pittsburgh plus" basing-point system for steel prices, in which "the delivered price of steel from anywhere in the United States to a point of delivery anywhere in the United States was in general the Pittsburgh price plus the railroad freight rate from Pittsburgh to the point of delivery." Id. Producers located between the basing point and their customers could thus charge customers "phantom freight" for transportation costs (measured from Pittsburgh) that were not actually incurred. 1d. at 697-98.

130. Id. at 714 (emphasis added); see also Haddock, Basing-Point Pricing: Competitive vs. Collusive Theories, 72 Am. Econ. Rev. 289, 292-93 (1982) (suggesting that basing-point pricing will occur in markets with dominant firms and fringe competition). 
Nonetheless, condition (1) suggests that evidence of either targeted or non-targeted punishment should not be used indiscriminately to prosecute members of a cartel. To the extent that evidence of actual punishment is used against the original price chiseler, it will reduce the expected profits from chiseling and thus make chiseling less desirable. This is because a firm contemplating breach will realize that breaching the cartel agreement may ultimately cause its own prosecution, with the attending criminal and treble damage liability. ${ }^{131}$ Using punishment episodes as evidence against the punishers, conversely, is desirable. Raising the costs of punishment will make severe punishments less credible, so cartels will tend to let more price chiseling go unpunished to society's benefit. ${ }^{132}$

\section{Conclusion}

The current structural approach fails to recognize the necessity of being able to punish breaches of cartel agreements. This Article has examined how cartels can punish price-chiselers, how threats of punishment can be made credibly, and what market characteristics will influence the size of the credible threat. Some characteristics (such as mostfavored-nation clauses) can clearly increase the ability to punish, others (such as the spillover and market-share effects on advertisement punishments) yield clear theoretical answers but may be difficult to identify in practice, and still others (such as product differentiation or capacity constraints) require more specific analysis to understand whether the cartel agreement is likely to be self-enforcing. ${ }^{138}$

While the ability to reach agreement may be an all-or-nothing variable, this Article has attempted to show that the ability to punish credibly will instead vary in magnitude. ${ }^{134}$ Thus, the need for selfenforcement will usually not be an impregnable barrier to collusion but instead will limit the degree of collusion-the amount by which firms can raise price above cost. ${ }^{135}$

131. Indeed, granting immunity from prosecution to any firm that informs the government about the existence of an antitrust conspiracy might be desirable. A breaching firm could then credibly threaten the non-breaching firms that it will turn state's evidence if it is punished for breaching. Such immunity might thus give breaching firms a powerfully competitive counterstrategy.

132. This policy may be difficult to implement because it may be difficult to identify which price-cutters were chiseling and which were punishing. The timing of the price changes may not always be clear. In addition, identifying nonprice punishments may be especially difficult. See, e.g., supra notes 53-57 and accompanying text.

133. The fact that different models can at times yield different results is not a failing of theory, but a reflection of economic complexity; it means only that with respect to cartel issues a careful and reasoned choice of model is necessary. See Schmalensee, On the Use of Economic Models in Antitrust: The Realemon Case, 127 U. Pa. L. Rev. 994, 995 (1979).

134. For example, almost any industry will be able to resort to pricing punishments of varying magnitude.

135. While this Article has isolated the determinants of punishment, the three pre- 
Finally, the analysis of punishment in this Article could also be extended to a host of diverse agreements that lack legal mechanisms for enforcement. For example, breaches of criminal conspiracies or international agreements cannot be rectified by resort to law. ${ }^{136}$ Similarly, the judicial branch will often abstain from enforcing political understandings between the executive and the legislature. ${ }^{137}$ The analysis here suggests that a structural approach might fruitfully be applied in these contexts as well to resolve the same issues of self-enforcement, punishment, and credibility.

requisites of collusion, see supra note 5 and accompanying text, do interact. Because self-enforcing collusive agreements must include punishment provisions, see supra text following note 12 , factors that influence the first prerequisite-the ability to reach agreement-will also indirectly affect the ability to punish. Additionally, the second prerequisite-the ease of detection-will, by determining the profits from breach, affect the needed punishment in a given industry. See supra text accompanying note 28.

136. M. McDougal \& W. Reisman, International Law in Contemporary Perspective 1223 (1981).

137. See, e.g., Baker v. Carr, 369 U.S. 186 (1962) (describing Supreme Court abstention on basis of "political question" doctrine). A number of academics have used a "legislation-as-contract" approach to statutory interpretation. See Easterbrook, The Supreme Court, 1983 Term-Foreword: The Court and the Economic System, 98 Harv. L. Rev. 4, I5 (1984); Macey, Promoting Public-Regarding Legislation through Statutory Interpretation: An Interest Group Model, 86 Colum. L. Rev. 223, 234 (1986) ("if the parties to a [legislative] contract believe that the bargain they are striking is unenforceable, the value of that contract will be significantly diminished"). 


\section{APPENDIX}

This appendix analyzes a simple model of advertising punishment to examine the tension between the spillover and market-share effects described in the text. ${ }^{138}$

Following Schmalensee, ${ }^{139}$ suppose that there are $N$ firms in an industry cartel with constant unit cost $(c)$. To simplify the analysis and to highlight the effect on advertising, assume that the cartel has agreed to sell at a fixed cartel price $(P)$ and to punish breaches by altering the amount of advertising. Finally, assume that each firm's demand (with the fixed, equal price) is determined by the amount it advertises relative to other firms. Specifically assume:

$$
q_{i}=\left[\sum_{j=1}^{N} A_{j}\right]^{a} \frac{A_{i}^{e}}{\sum_{j=1}^{N}\left(A_{j}\right)^{e}}, \text { for } i=1 \text { to } N
$$

where $A_{i}$ is firm $i$ 's advertising spending and $q_{i}$ is its unit sales. While appearing formidable, this demand equation can be easily interpreted. The parameter $a$ is a constant between zero and one, which measures the spillover effect-the elasticity of total market demand with respect to the amount of advertising outlays. The positive parameter $e$ measures the market-share effect-the "sensitivity of firms' market shares to differences among their advertising outlays." 140

The profits of each firm, $\pi_{i}$, are then:

$$
\pi_{i}=(P-c) q_{i}-A_{i}
$$

Deriving the symmetric first-order equations for the collusive equilibria we find:

$$
\frac{A_{\text {col }}}{(P-c) q_{\text {col }}}=a
$$

and for the competitive (Nash) equilibria:

$$
\frac{\mathrm{A}_{\text {com }}}{(\mathrm{P}-\mathrm{c}) \mathrm{q}_{\mathrm{com}}}=\frac{\mathrm{e}+(\mathrm{a}-\mathrm{e})}{\mathrm{N}}
$$

where $A_{\text {col }}$ and $q_{\text {col }}$, ( $A_{\text {com }}$ and $q_{\text {com }}$ respectively) represent the advertising expenditures and output of each firm for the collusive (competitive) equilibrium. The relationship between the output levels and advertising expenditures in both equations (App3) and (App4) can be characterized as follows:

$$
\mathrm{q}=\mathrm{N}^{\mathrm{a}-1} \mathrm{~A}^{\mathrm{a}}
$$

Substituting equation (App5) into equation (App3) and (App4), we can derive the result of interest that $A_{\text {col }}$, the collusive amount of advertis-

138. See supra notes $51-55$ and accompanying text.

139. Schmalensee, supra note 51 , at 375 .

140. Id. 
ing, will equal $A_{\text {com }}$, the competitive amount of advertising, if and only if:

$$
\operatorname{sign}\left(A_{\text {col }}-A_{\text {com }}\right)=\operatorname{sign}(a-e)
$$

The interpretation of equation (App6) is that collusive advertising expenditures will be greater than competitive advertising expenditures if and only if $a$ is greater than $e$-that is, if and only if the advertising elasticity of market demand is greater than the sensitivity of firms' market shares to advertising differences. When the spillover effect of advertising is greater than the market-share effect, collusion will increase advertising spending. This means that punishing via advertisement can entail either increasing or decreasing the collusive rate. When $a=e$, the spillover effect and the market-share effect exactly cancel each other so that $A_{\text {col }}$ and $A_{\text {com }}$ will be the same. In this situation credible advertising punishments are not possible because neither the level of advertising nor the breaching firm's profits will be affected.

For other strategic variables (such as quality) that affect firm's relative market share, but that do not involve a spillover effect, $a$ will be zero, so that the collusive equilibrium amounts will be unambignously less than the competitive/punishment levels. 